\title{
The Relation between Disclosure Quality and Information Asymmetry: Empirical Evidence from Iran
}

\author{
Dariush Bahmani ${ }^{1}$ \\ ${ }^{1}$ Lavasanat branch of Payame Noor University, Iran \\ Correspondence: Dariush Bahmani, Lavasanat branch of Payame Noor University, Iran. E-mail: \\ farzad_hotline@yahoo.com
}

Received: January 1, 2014

Accepted: February 9, 2014

Online Published: March 31, 2014

doi:10.5430/ijfr.v5n2p110

URL: http://dx.doi.org/10.5430/ijfr.v5n2p110

\begin{abstract}
Information asymmetry and management incentive make important problem in the efficient allocation of resources in a capital market. Improving disclosure quality have crucial role in mitigating these problems. This study examines the relationship between disclosure quality and information asymmetry in TSE. To examine this hypothesis, 125 companies listed in TSE, during 2008 up to 2012 have been studied. The first hypothesis suggests that there is a negative relationship between the quality of corporate disclosure and earnings quality. This result shows that disclose financial information in reliable and timeliness manner decrease information asymmetry in form of earning quality.
\end{abstract}

Keywords: disclosure quality, earnings quality, information environment, information asymmetry

\section{Introduction}

Information asymmetry in the form of adverse selection and moral hazard has a different adverse outcomes, such as transaction costs, low liquidity market and increasing cost of capital. In these manner management has incentive to disclose more information about their current financial condition and prospect of their company voluntarily and therefore reduce this asymmetry. In addition, market regulator, to improve capital allocation and protecting investors, legislate disclosure code in order to reduce information asymmetry between outside stockholders and firm management. Any decision, regarding the purchase or sale of stocks, requires detailed knowledge of the return and risk. In one side, investors want to maximize their return against the risk of their investment and on the other side, management wants to maximize their firm value and their compensation. Therefore, investors build bridges between information asymmetry and expected return to allocate their resource efficiently. Since the information asymmetry affects different type of investors, creditors and financial analysts, evaluating the impact of information asymmetry seems to be necessary. Since level of information asymmetry cannot consider directly so researcher uses different type of approach to measure this phenomenon. In one approach information asymmetry, in the form of information Quality, is important for people in every stage of the creation, dissemination and use of information for the allocation of capital. But research on the effect of information asymmetry on disclosure quality have been inconsistent. Some earlier research, showed that there are Substituting relation between information asymmetry and the quality of disclosure. This study have argued that increasing information asymmetry (Low quality Income) between individuals within the organization and shareholders whereby the incentive for voluntary disclosure. While other studies have found a complementary relation between earnings quality and disclosure, and argue that more quality information cause managers have a greater incentive to disclose more and better information. (Dye, 1985). Given this conflict, this study examined the relation between earnings quality, as a measure of information asymmetry, and the quality of disclosure. We try to examine the issue of whether the main factor affecting the disclosure quality is existence of internal information?

\section{Literature and Conceptual Framework}

Accounting Information must be relevant to evaluate of past, present and future event. In addition, the information provided in the financial statements must be reliable and do not have any errors that may cause consumer confuse and make an erroneous decisions. Therefore recognition, measurement and disclosure of accounting information can be effective in market view and financial condition. Financial statements should be on underlying assumptions and estimate accounting items according to issue of uncertainty that have important effects on the company's financial picture. Because of relevant information decrease information asymmetry between company management and outside 
investors, market participants always are looking for high quality financial information. There are numerous studies in the accounting literature that demonstrate achievement of higher disclosure quality, reducing information asymmetry. According to the findings of Francis and Wang (2008) extensive disclosure policy is a mechanism that reduces information asymmetry between managers and outside investors. Glosten and Milgrom (1982) present the relation between corporate disclosure and information asymmetry in terms of the model. Their model shows that corporate disclosure information asymmetry level increases to decreases in disclosure. Walker (1995) findings show that the information asymmetry and market liquidity increases proportionally to the decrease and increase in disclosure, respectively. Lang and Lundholm (1993) present evidence which indicates that informative disclosure policies result to more follower analysts, more accurate earnings forecasts by analysts and less dispersion among analysts' forecast. These results indicate that informative disclosure policy reduces information asymmetry. Point of importance is the recognition of items in the financial statements is affected by accountant estimates. Accounting disclosure should look to the future visions of opportunities and risks that face the company. Disclosure may be critical to the company's financial position when there is uncertainty and risk around company.

Company's financial reporting and disclosure is essential due to information asymmetry and the agency problem among companies and their stockholders. Accounting disclosure led to greater market liquidity and reduced the company's cost of capital (Healy and Palepu, 2001; Diamond and Verrecchia, 1993). Some research are believed information asymmetry associated with earnings quality and earnings quality is considered as a measure of information asymmetry (Verrecchia, 1990). As a result, the quality of corporate disclosure and earnings quality have a negative or substitute relation. This means that firms with low earnings quality, reveal more information with more quality. However, this argument ignores this fact that disclosing are based on low quality information (earning quality). Thus we can say that under rational expectations, there is little validity for this type of disclosure (Francis et al,2008). Easler and O'Hara (2004) showed that if the amount of secret information is more than data reported, due to information asymmetry, estimation risk of investors increase and they are asking more return. In this context, Lang and Lundholm (1997) found firm with a weak correlation between the returns of companies and Interest rates, have higher disclosure. (The substantive relation)

However, some studies result that there is complementary relationship between disclosure quality and earnings quality. It means, if the quality of financial reporting or earnings quality increases, managers are more motivated to disclose more information. Jung and Kwon. (1988) consider Information quality as the probability manager has confidential information and study disclosure or non-disclosure of information about the decisions. The more risk of confidential information, the more likely to follow it. The reason can be expressed in this way is not disclosing information by manager are considered as bad news by market and thus the value of the company are reduced. Companies to reduce information asymmetry and cost of capital, are motivated to do the highest level of disclosure. In this circumstances, the cost of information disclosure include risk sharing, agency costs and ownership costs (Diamond and Verrecchia, 1991; Hayes and Lundholm 1996). This cost eliminates advantage due to lower cost of capital and thereby cause to the lack of full disclosure of information by companies. Botosan and Plumlee (2002) found that high-quality financial reporting reduces the cost of capital. In this scope, Ghosh and Doocheol (2010) investigated the relation between financing by debt and earnings quality. Using accruals quality criteria for measuring the quality of earning, study show there are nonlinear relation between debt financing and earnings quality.

Important part of the literature on disclosure examine the quality of voluntary disclosure in response to information asymmetry existence. The endogenous voluntary disclosure investigated by Gietzmann and Trombetta (2003). They found that firms communicate information about their condition voluntarily by disclosing high quality information and selection of accounting policies. As a result of voluntary disclosure for venture firms, accounting policies affects the cost of capital. models without considering the relationship between disclosure quality and earnings quality, consider high-quality voluntary disclosure in response to the quality of financial information.

In relevant study there are two basic approaches for measuring disclosure quality have evolved within the academic literature. The first involves direct disclosure scoring by the researcher based on a self-developed disclosure index. Examples constitute Wiseman (1982) and Botosan (1997). The second involves the use of external ratings of disclosure such as those published in TSE. This study is based on the second approach, although each method has its own advantages and disadvantages. Subjective judgment by researcher's disclosure index could be named as a disadvantage of the first approach. As such, the index may not fully reflect the views of relevant user groups such as investors, creditors or financial analysts; On the other hand its advantage is due to its Applicability to a broad cross section of firms and not being restricted to those firms covered by the external agency (Artiach and Clarkson 2010). According to literature and the importance of disclosure in business realm, the problem this research seeks to embark 
is whether disclosure quality whether internal information cause to disclose more. Thus the followings is the research hypothesis:

Main hypothesis: There is a significant relationship between earnings quality and the quality of disclosure.

\section{Research Method and Data Collection}

TSE gauges disclosure quality of listed firms according to their reliability and relevance, the results which are published annually are finally summarized as a score and are assigned to each firm. One of the fundamental attributes of relevance is timeliness, an influencing factor on firm's score to wit forecast of return on stock, quarterly financial statements, portfolio condition, dividend payout schedule and etc. reliability points to standard deviation of financial forecasts and the difference between actual results and budget statements sent to TSE. Bankruptcy criterion is base on article 141 of commercial codes of Iran, information related to bankrupt firms are gathered one year prior to actual bankruptcy.

In the financial literature generally three classes of alternative measures of information asymmetry have been proposed: accounting based measurement, measurement that is based on analysts' earnings forecast and market based measurement. Accounting based measurement focus on accrual and their quality. Reason of this interest is importance of accrual part relation to cash part to assessment of company performance. Cash part that obtained during a financial period has a few news about future cash flow and therefor is not relevant to decision making. In the other word, cash part of earning cannot lead to a correct measurement of corporate performance. I this view accrual accounting reduce this problems and transfer ongoing benefit to current financial statement. The main benefit of this transition is that the adjusted figures have more accurate picture of the economic performance of the company affair. High accrual quality have some accurate signal about future performance and transfer internal information of management ti outside body. The first model of this study to assess the quality of earnings. We use modified accruals quality model that is used by Mcnicholas (2002) according to Dechow and Dichev (2002) adjustment. In this model, accruals are based on cash flows separate by cash flow relation. This model regress changes in working capital accruals on cash flows in prior, current, and future changes in income and fixed assets (property, plant and equipment). Error term changes in working capital (the model error), is as an inverse indicator of earnings quality and therefore higher unexplained portion is a proxy of lower earnings quality. The model is as follows.

Model A:

$$
\triangle W C i, t=\beta 0+\beta 1 C F O i, t-1+\beta 2 C F O i, t+\beta 3 C F O i, t+1+\beta 4 \Delta R E V i, t+\beta 5 P P E i, t+e i,
$$

$\triangle \mathrm{WC} \mathrm{i}, \mathrm{t}=$ Changes in working capital. Working capital is defined as Current assets minus current liabilities and cash of the firm $i$ at the end of the year $t$.

$\mathrm{CFO} i, \mathrm{t}=$ Cash flow from operating activities of the firm $\mathrm{i}$ at the end of the year $\mathrm{t}$.

$\triangle \mathrm{REV} i, \mathrm{t}=$ Change in revenues year $\mathrm{t}$ to year $\mathrm{t}-1$ of the firm $\mathrm{i}$.

PPE $i, t=$ Gross value of property, plant and equipment of the firm $i$ at the end of the year $t$.

All of the above variables are divided to total assets of the company to the same scale. Earnings Quality Index, the standard deviation of the residual errors in duration (5 years) looking for any company. The standard deviation of the residual errors for each firm, the greater is the lower earnings quality. In addition, TSE gauges disclosure quality of listed firms according to their reliability and relevance, the results which are published annually are finally summarized as a score and are assigned to each firm. One of the fundamental attributes of relevance is timeliness, an influencing factor on firm's score to wit forecast of return on stock, quarterly financial statements, portfolio condition, dividend payout schedule and etc. reliability points to standard deviation of financial forecasts and the difference between actual results and budget statements sent to TSE.

The study population included all companies accepted in Tehran Stock Exchange during the 2005 to 2012 according to the many restrictions. Using random sampling limitations, the number of the years 2005 to 2012 companies were selected. To investigate the relationship between disclosure quality (dependent variable) and earnings quality (independent variable) model following control variables affecting the quality of disclosure has been studied. According to the literature, firm size (log of market value), growth (log of market value to book value of equity) and return on assets (earning divided by total assets) as a control variable, (Lang and Lundholm, 1993).

Second model:

$$
\operatorname{Dis} Q i, t=\beta 0+\beta 1 A Q i, t+\beta 2 R O A i, t+\beta 3 \operatorname{SIZE} i, t+\beta 4 B T M i, t+e i, t
$$

DisQ $i$, t: In this study, to assess quality of disclosure we use corporate rating issued by the TSE. 
AQ $i, t$ : The quality of accruals obtained from the model A.

ROAi, $t$ : Earning divided by the assets of the firm $i$ at the end of the year $t$.

SIZEi, $t$ : Natural logarithm of the market value of equity firm $i$ at the end of the year $t$.

BTM i, t: Natural logarithm of book value to market value of equity of the firm $i$ at the end of the year $t$.

\section{Research Findings}

After data collection for all variables, descriptive statistics are presented in Table 1. Distribution of size, performance measurement and asset growth reflects an appropriate range of companies included in the sample. To test the first hypothesis sought to determine the relationship between earning quality and quality of disclosure is provided in Table 2. On this basis, Coefficient $\beta 1$ was positive (0.141) in confidence level. $99 \%$ is significant. The coefficient implies an inverse relation between disclosure quality and earnings quality. This result verified first research hypothesis. We can say, low earning quality has offset by high disclosure quality. Base on this observation, there is a substitution relation between disclosure quality and earnings quality.

Table 1. Descriptive data

\begin{tabular}{lllllll}
\hline variable & & & & & \\
\hline & BM & disQ & Earning quality & ROA & Beta & Size \\
& 0.75 & 50.24 & 0.09 & 0.12 & 0.39 & 13.96 \\
& 0.61 & 50.51 & 0.06 & 0.11 & 0.09 & 13.05 \\
& 0.54 & 22.10 & 0.10 & 0.12 & 1.24 & 14.62 \\
\hline
\end{tabular}

Table 2. Regression result

\begin{tabular}{llllll}
\hline & \multicolumn{5}{c}{ Dis $Q_{i, t}=\beta_{0}+\beta_{1} A Q_{i, t}+\beta_{2} R O A_{i, t}+\beta_{3} S I Z E_{i, t}+\beta_{4} B T M_{i, t}+e_{i, t}$} \\
\hline & $\beta_{4}$ & $\beta_{3}$ & $\beta_{2}$ & $\beta_{1}$ & $\beta 0$ \\
\hline Coefficient & 0.002 & -0.085 & $* * 0.349$ & $* * 0.141$ & $* * 51.346$ \\
& 0.044 & -1.648 & 6.485 & 2.887 & 7.295 \\
& $* * 14.525$ & & & & \\
\hline F statistic & & & & $: 12.5 \%$ adjusted R \\
\hline
\end{tabular}

\%significant in $99 *$

\section{Conclusion}

With regard to the issue of importance of information asymmetry in the capital market and its role in investor confidence, this study examines the conflict between disclosure quality and earnings quality as measures of information asymmetry in financial environment. The results of testing the first hypothesis show that there is a significant relation between disclosure quality and earnings quality criteria. In the other words, the increase in information asymmetry has led the company to eliminate any possible unpleasant consequences, they have incentive to increase the quality of reliable disclosure in timely basis. Findings of provided models verify the substitution relationship between the quality level of disclosure and information asymmetry criteria. This relation is unlike the findings of Francis et all (2008). Increasing the level of disclosure quality respond to information asymmetry by company, is considered as evidence for increased estimates of the risks, impose higher cost of capital. This evidence is consistent with the results of Botosan end Plumlee (2002), Zhang (2001).

\section{Refrences}

Artiach, T. C., \& Clarkson, P. M. (2011). Disclosure, conservatism and the cost of equity capital: A review of the foundation literature. Accounting \& Finance, 51, 2-49. http://dx.doi.org/10.1111/j.1467-629X.2010.00387.x

Botosan, C. (1997). Disclosure level and the cost of equity capital. The Accounting Review, 72, 323-349. 
Botosan, C., \& M.Plumlee. (2002). A Re-examination of Disclosure Level and the Expected Cost of Equity Capital. Journal of Accounting Research, 21-40. http://dx.doi.org/10.1111/1475-679X.00037

Dechow, P., \& I.Dichev. (2002, Supplement). The Quality of Accruals and Earnings: The Role of Accrual Estimation Errors. The Accounting Review, 77, 35-59. http://dx.doi.org/10.2308/accr.2002.77.s-1.35

Diamond, D., \& R.Verre cchia. (1991). Disclosure, Liq uidity, and the Cost of Capital. Journal of Finance, 1325-1359. http://dx.doi.org/10.1111/j.1540-6261.1991.tb04620.x

DYE, R. (1985). Disclosure of Nonproprietary Information. Journal of Accounting Research, 23, 123-45. http://dx.doi.org/10.2307/2490910

Easler, D., \& M.O'Hara. (2004). Information and the Cost of Capital. Journal of Finance, 59(1), 553-83.

Francis, J., \& Wang, D. (2008). The joint effect of investor protection and Big 3 auditson earnings quality around the world. Contemporary Accounting Research, 72(1), 122-191. http://dx.doi.org/10.1506/car.25.1.6

Francis, J., D. Nanda, \& P. Olsson. (2008). Voluntary Disclosure, Earnings Quality, and Cost of Capital. Journal of Accounting Research, 46, 53-99. http://dx.doi.org/10.1111/j.1475-679X.2008.00267.x

Ghosh, A., \& Doocheol Moon. (2010). Corporate Debt Financing \& Earnings Quality. Journal of Business Finance \& Accounting, 37, 538-559. http://dx.doi.org/10.1111/j.1468-5957.2010.02194.x

Gietzmann, M.B., \& M. Trombetta. (2003). Disclosure Interactions: Accounting Policy Choice and Voluntary Disclosure Effects on the Cost of Raising Capital. Accounting and Business Research, 33, 187-205. http://dx.doi.org/10.1080/00014788.2003.9729646

Glosten. R., \& Milgrom, R. (1982, March). Bid, ask and transaction prices in a specialist market with heterogeneously informed traders. Journal of Financial Economics, 13(1), 21-100.

Hayes, R., \& R. Lundholm. (1996). Segment Reporting to the Capital Market in the Presence of a Competitor. Journal of Accounting Research, 34, 261-79. http://dx.doi.org/10.2307/2491502

Healy, P., \& K. Palepu. (2001). Information Asymmetry, Corporate Disclosure, and the Capital Markets: A Review of Empirical Disclosure Literature. Journal of Accounting and Economics, 31, 485-520. http://dx.doi.org/10.1016/S0165-4101(01)00018-0

Jung, W. O., \& Y.K.. Kwon. (1988). Disclosure When the Market Is Unsure of Information Endowment of Managers. Journal of Accounting Research, 26, 146-53.

Lang, M., \& Lundholm, R. (1993). Cross-sectional determinants of analysts ratings of corporate disclosures. Journal of Accounting Research, 31, 246-271. http://dx.doi.org/10.2307/2491273

Lang, M., \& Lundholm, R. (1997). Voluntary disclosure during equity offerings: reducing information asymmetry or hyping the stock? Contemporary Accounting Research, 17(4), 623-662. http://dx.doi.org/10.1506/9N45-F0JX-AXVW-LBWJ

Mcnicholas, M. (2002, Supplement). Discussion of the Quality of Accruals and Earnings: The Role of Accrual Estimation Errors. The Accounting Review, 77, 61-9. http://dx.doi.org/10.2308/accr.2002.77.s-1.61

Verrecchia, R. (1990). Information Quality and Discretionary Disclosure. Journal of Accounting \& Economics, 12, 365-380. http://dx.doi.org/10.1016/0165-4101(90)90021-U

Walker, M. (1995). Disclosure Policy, Information Asymmetry, and Liquidity in Equity Markets. Contemporary Accounting Research, 11, 801-827. http://dx.doi.org/10.1111/j.1911-3846.1995.tb00467.x

Wiseman, J. (1982). An evaluation of environmental disclosures made in corporate annual reports. Accounting, Organizations and Society, 7(1), 53-63. http://dx.doi.org/10.1016/0361-3682(82)90025-3

Zhang, G. (2001). Private Information Production, Public Disclosure, and the Cost of Capital: Theory and Implications. Contemporary Accounting Research, 18, 363-84. http://dx.doi.org/10.1506/N6G3-RWX7-Y15L-BWPV 